UDK: $\quad 336.717 .22: 004.3 / .4$

$347.457: 004.3 / .4$

$336.763 .5: 004.3 / .4$

347.72.031:004.3/.4

Primljeno: veljača 2021

Izvorni znanstveni rad

DOI: 10.32984/gapzh.12.1.2

\author{
dr. sc. Edita Čulinović-Herc* \\ dr. sc. Antonija Zubović \\ dr. sc. Morana Derenčinović Ruk
}

\title{
UTJECA] MODERNIH TEHNOLOGIJA NA POSREDNO DRŽANJE DIONICA - NACIONALNI MODELI I GLOBALNA PERSPEKTIVA
}

Razvoj modernih, globalno primjenjivih tehnologija utječe osobito na dionička društva čijim se dionicama trguje na tržištu kapitala. Jedna je od njih blockchain (dalje u tekstu: BC) tehnologija koja je podvrsta tzv. tehnologije distribuirane glavne knjige (dalje u tekstu: DLT). Kako su dionice nematerijalizirani vrijednosni papiri, u hrvatskom pravu, kao i u drugim pravnim poredcima, podatke o nematerijaliziranim vrijednosnim papirima i njihovim imateljima najčešće vodi središnje tijelo, odnosno operater središnjeg depozitorija vrijednosnih papira. Također, opća je pojava da se dionice drže putem posrednika, koji često bivaju globalno ulančani, pogotovo u prekograničnoj trgovini. No smatra li se u tom slučaju zakonitim imateljem vrijednosnih papira sam ulagatelj ili (neki od) posrednik(a), različito je pravno riješeno na komparativnoj osnovi te je bilo predmetom pravnog ujednačavanja. U radu se nakon iznošenja komparativnih modela o tome tko se smatra zakonitim imateljem vrijednosnog papira kada ga drži posrednik iznose obilježja hrvatskog sustava u razvojnom kontekstu i sadašnje perspektive imajući u vidu i utjecaj europskog prava. U zadnjem dijelu rada, nakon iznošenja temeljnih obilježja BC tehnologije, kritički se motri na koji bi način njezina primjena promijenila

Dr. sc. Edita Čulinović-Herc, redovita profesorica u trajnom zvanju na Katedri za trgovačko pravo i pravo društava, Sveučilište u Rijeci, Pravni fakultet i redovita članica Akademije pravnih znanosti Hrvatske (Full Professor tenure, Chair of Commercial Law and Company Law, Faculty of Law, University of Rijeka and full member of the Croatian Academy of Legal Sciences): edita@pravri.hr

ORCID ID: orcid.org/0000-0002-6177-8057

** Dr. sc. Antonija Zubović, docentica na Katedri za trgovačko pravo i pravo društava, Sveučilište u Rijeci, Pravni fakultet i redovita članica Akademije pravnih znanosti Hrvatske (Assistant Professor, Chair of Commercial Law and Company Law, Faculty of Law, University of Rijeka and full member of the Croatian Academy of Legal Sciences): azubovic@pravri.hr

ORCID ID: orcid.org/0000-0001-8238-3495

*** Dr. sc. Morana Derenčinović Ruk, HANFA, Zagreb (Croatian Financial Services Supervisory Agency, Zagreb,Croatia): morana.derencinovic@hanfa.hr, mderencinovic@gmail.com

ORCID ID: orcid.org/0000-0002-6624-7896

Stavovi koautorice Morane Derenčinović Ruk osobni su i ne predstavljaju službeni stav HANFA-e.

Ovaj rad financiralo je Sveučilište u Rijeci projektom „Pravni aspekti restrukturiranja trgovačkih društava i tranzicija prema novoj kulturi korporativnog upravljanja“" (uniridrustv-18-43). 
postojeći sustav vođenja upisnika o vrijednosnim papirima s jedne strane te na koji način to utječe na posredno držanje dionica s druge strane.

Ključne riječi: blockchain, tehnologija distribuirane glavne knjige (DLT tehnologija), vrijednosni papiri koji se drže putem posrednika, središnji depozitorij vrijednosnih papira.

\section{UVOD}

Pojam vrijednosnog papira još uvijek uključuje ispravu iako su nematerijalizirani vrijednosni papiri već odavno u primjeni na hrvatskom tržištu kapitala. Kada je riječ o dionicama, dionica se pod pritiskom tržišnih okolnosti odvojila od isprave još u prošlom stoljeću. Prvi korak bila je tzv. imobilizacija vrijednosnog papira. Do toga je došlo zbog povećanja obujma trgovanja, prije svega na burzama u SAD-u, tijekom 60-ih

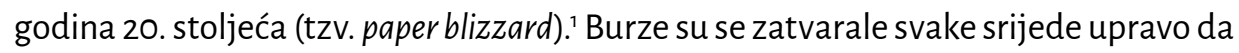
bi se mogla provjeriti autentičnost svih isprava koje su pratile transakciju. ${ }^{2}$

S imobilizacijom, dionica je i dalje postojala kao isprava, ali je bila deponirana u instituciji pod nazivom Depository Trust and Clearing Corporation (DTCC). Izmijenjeni i dopunjeni Securities Act iz 1975. godine ${ }^{3}$ pri namiri transakcija uvažio je okolnost "imobilizacije“ dionica te više nije bilo bitno gdje se nalaze isprave. $U$ tom sustavu izdavatelji vrijednosnih papira, tj. dionička društva, otvarali su račune u elektroničkom sustavu središnjeg depozitorija, a namira se odvijala preknjižbom s računa na račun. No, u etapi imobilizacije nije bilo uobičajeno da ulagatelj/dioničardrži račun pri DTCC-u, većje to za njega držao posrednik. To je prema nekim autorima ${ }^{4}$ dovelo do promjene paradigme odnosa dioničara i društva unutar kojeg su se (trajno) nastanili posrednici. Dakle, ulagatelj/dioničar držao je račun kod nekoga financijskog posrednika, a potonji je držao račun kod središnjeg depozitorija izravno ili opet preko drugog posrednika. ${ }^{5}$

Idući korak bila je dematerijalizacija vrijednosnih papira koja je bila tijesno povezana s tadašnjim mogućnostima informatičke tehnologije. Pravo iz papira više nije bilo zapisano u ispravi, već je postojalo kao elektronički zapis koji se vodi na računu vrijednosnih papira u tome istom središnjem depozitoriju vrijednosnih papira ${ }^{6}$

Skrbništvo nad dionicama zahvaljujući imobilizaciji i dematerijalizaciji doživjelo je pravu renesansu. Tu leže početci stvaranja kompleksnih lanaca posrednog držanja dionica koji su se dodatno ulančavali u prekograničnim transakcijama. Posrednič-

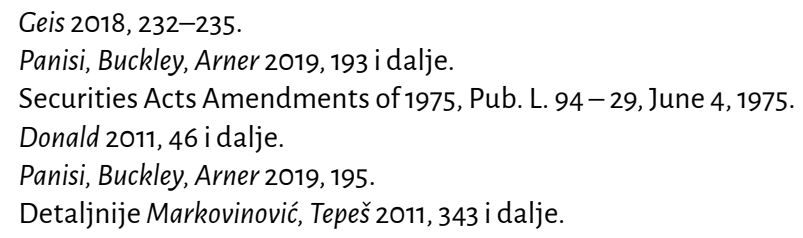


ke strukture mogle su se replicirati i vodoravno i okomito ${ }^{7}$ te su postajale sve dulje i kompleksnije. ${ }^{8}$ No problem je nastajao u tome što je svakim prelaskom „državne granice" navedeni vrijednosni papir ulazio u drugo regulatorno okružje koje je na različite načine odgovaralo na pitanje tko se smatra zakonitim imateljem dionice-ulagatelj ili posrednik. Sama okolnost da je netko angažirao posrednika nije nužno dovodila do toga da je posrednik postajao zakoniti imatelj dionice. To je ovisilo o tome je li pojedini pravni sustav prihvatio izravno ili neizravno držanje preko posrednika. U modelu tzv. izravnog držanja ulagatelj (dioničar) i dalje je zadržavao položaj zakonitog imatelja. Kod posrednog je držanja ulagatelj angažiranjem posrednika prestajao biti njezin zakoniti imatelj. Za potonju varijantu uvriježio se izraz posredno ili neizravno držanje dionica (indirect holding system - IHS). ${ }^{9}$

\section{KOMPARATIVNI MODELI ODREĐIVANJA ZAKONITOC IMATELJA PRI DRŽANJU VRIJEDNOSNIH PAPIRA PUTEM POSREDNIKA}

U transakcijskim uvjetima koji podrazumijevaju prelazak državne granice ključno je znati koje pravo uređuje pitanje tko se smatra zakonitim imateljem vrijednosnog papira kojeg se često, komparativnopravno gledano, naziva „vlasnikom“. U nastavku se u sažetom obliku iznose razlikovna obilježja komparativnih modela.

Te razlike dovele su do pokušaja unifikacije s jedne strane kolizijskihi' ${ }^{10}$, a s druge strane materijalnopravnih rješenja. Primjer je za potonji UNIDROIT-ova Konvencija o materijalnom pravu za vrijednosne papire koje drže posrednici koja ima samo jednu

\footnotetext{
7 Kunda 2011, 306 i dalje.

8 Van der Elst, Lafarre 2019, 117.

9 Umjesto svih vidi Panisi, Buckley, Arner 2019, 196-200.

${ }_{10}$ Posebice Convention of 5 July 2006 on the Law Applicable to Certain Rights in Respect of Securities held with an Intermediary (Haška konvencija o pravu mjerodavnom za vrijednosne papire koje drže posrednici, dalje u tekstu: Haška konvencija), 5 July 2006. Dostupno na https://assets.hcch.net/ docs/3afb8418-7eb7-4aoc-af85-c4f35995bb8a.pdf (20. 5. 2020.). Donesena je 5. srpnja 2006. godine u Nizozemskoj, a stupila je na snagu 1. travnja 2017. Ratificirali su je Mauricijus, Švicarska i SAD. Europska komisija preporučila ju je državama članicama na potpisivanje u srpnju 2006. godine, ali je ta preporuka naknadno povučena. U njoj se razrađuje tzv. PRIMA pristup pri određivanju mjerodavnog prava. Upućivanje na mjesto relevantnog posrednika (PRIMA, engl. The Place of Relevant Intermediary Approach) tražilo je mogućnost određivanja njegova situsa. No, Haška konvencija nadišla je tu početnu formulaciju PRIMA kriterija odbacivši metode određivanja mjesta nalaženja odnosnog posrednika, zamjenjujući ga izričitim dogovorom između vlasnika računa i njegova posrednika uz dodatni uvjet kvalificirajućeg ureda (engl. qualifying office). Kvalificirani ured test je realnosti, a obilježja su mu navedena u čl. 4., st. (1) Haške konvencije i čine „bijelu listu“ okolnosti koje predstavljaju pozitivne zahtjeve te "crnu listu“ kao okolnosti koje nisu dostatne same po sebi da bi se ured posrednika smatrao kvalificiranim uredom. Haška konvencija sadržava i niz rezervnih odredbi o određivanju mjerodavnog prava u čl. 5.
} 
potpisnicu i nije do sada stupila na snagu." UNIDROIT je u nastavku donio i Vodič za vrijednosne papire koje drže posrednici (dalje u tekstu: UNIDROIT-ov vodič) ne bi li povećao izglede za implementaciju konvencijskih rješenja jer je UNIDROIT-ov vodič usmjeren na nacionalne zakonodavce. $U$ ovom radu koristimo se njime kako bismo u sažetom obliku prikazali šarolikost nacionalnih rješenja koje je UNIDROIT-ov vodič sažeo u pet modela. ${ }^{2}$

Prvi je model individualnog „vlasništva“ ulagatelja (engl. Individual ownership model). Prema tom modelu, koji UNIDROIT identificira svojstvenim francuskom pravu' ${ }^{13}$, ulagatelj ima individualno „vlasništvo nad vrijednosnim papirima“. Posrednici odnosno središnji depozitoriji vrijednosnih papira nemaju nikakva prava nad tim vrijednosnim papirima, osim u slučaju ako je neki posrednik na tome vrijednosnom papiru stekao osiguranje tražbine. Drugi je model podijeljenog/zajedničkog "vlasništva“ (co-ownership / fractional ownership). Tim sustavima svojstveno je da izdavatelj deponira vrijednosne papire u središnji depozitorij u obliku globalne potvrde (engl. global certificate, Globalurkunde). Središnji depozitorij upisuje te vrijednosne papire na račune svojih sudionika, u pravilu banaka koje opet te račune drže za druge financijske posrednike ili za ulagatelje. $U$ tom modelu ulagatelj ima $u$,idealnom dijelu vlasništvo" nad fungibilnim poolom vrijednosnih papira što ih ukupno drži središnji depozitorij. ${ }^{14}$ Treći je model trust (engl. trust model), svojstven Ujedinjenom Kraljevstvu, Irskoj i Australiji. Vrijednosni papiri pohranjeni su u središnjem depozitoriju. U njemu se samo upisuju dionice i depozitorij ne stječe nikakva stvarnopravna ovlaštenja. Posrednici koji su njegovi članovi (banke skrbnici) nominalni su „vlasnici“ vrijednosnih papira, bilo da ih drže za sebe bilo za račun svojih klijenata. Kada posrednik počne držati vrijednosni papir za drugog, a ne više za sebe, on postaje njihov trustee, a klijent postaje beneficijalni "vlasnik“ (engl. Beneficiary). ${ }^{5}$ Četvrti je model tzv. security entitlement model svojstven SAD-u. Skup prava i interesa tzv. ovlaštenika glede prava iz vrijednosnog papira koji drži posrednik znači da svaki „vlasnik“ računa vrijednosnih papira (engl. account holder) ima sui generis skup prava koja može isticati

1 UNIDROIT Convention on Substantive Rules for Intermediated Securities, 9. 10. 2009. Dostupno na https://www.unidroit.org/instruments/capital-markets/geneva-convention (5. 5. 2020.).

${ }_{12}$ UNIDROIT Legislative guide on intermediated securities. Dostupno na https://www.unidroit.org/instr-capitalmarkets-legislative-guide (10. 6. 2020.).

13 Krug država koje se koriste tim modelom mnogo je širi. Naziva se još i nordijskim modelom, ali obuhvaća velik broj država. V. izlaganje pod točkom 3. rada.

14 Van der Elst, Lafarre 2019, 117. Ulagatelj pristupa svojim vrijednosnim papirima preko svog posrednika tako da svi oni posrednici koji se nalaze „iznad“ toga relevantnog ulagateljeva posrednika (engl. relevant intermediary) ne mogu odrediti udjel koji kao dio tog poola pripada određenom ulagatelju.

15 Korisnik stječe nad tim vrijednosnim papirima tzv. equitable interest. Ulagatelj može pristupiti svojim vrijednosnim papirima samo preko relevantnog posrednika kojeg je sam odabrao, a ne preko onih koji dalje lančano drže te vrijednosne papire. U slučaju da posrednik postane insolventan, ulagatelj kao korisnik ima proprietary interest na vrijednosnim papirima u koje vjerovnici posrednika ne mogu zadirati. 
prema posredniku u vezi s financijskom imovinom koju taj drži. ${ }^{16}$ No, svaki imatelj računa to može činiti u odnosu na svoga relevantnog posrednika. To pravo ima i svaki posrednik u lancu koji se nalazi „ispod“ središnjeg depozitorija. lako taj ovlaštenik nema mogućnost ostvarivanja imovinskih i drugih prava iz tih vrijednosnih papira izravno prema izdavatelju, posrednik ima obvezu pribaviti i prenijeti (engl. pass on) prava iz vrijednosnih papira za račun onoga tko je entitlement holder. ${ }^{17}$ Peti je model ugovorni model (engl. contractual model). Ulagatelj prema njemu ne stječe stvarnopravna ovlaštenja (engl. proprietary interest) na vrijednosnom papiru, već samo ugovorna prava prema svome relevantnom posredniku. Središnji depozitorij ili neki drugi posrednik pojavljuje se u izdavateljevu upisniku kao registrirani imatelj, nakon čega prava i koristi iz tih vrijednosnih papira putuju posredničkim lancem od posrednika do posrednika, a na kraju su dostupni i ulagatelju. ${ }^{18}$

Svi ti modeli mogu se svrstati u transparentne ili netransparentne sustave. Ako je riječ o transparentnom sustavu, središnji depozitorij može identificirati ulagatelja ili mu je poznat jer se uloga vođenja računa vrijednosnih papira dijeli između središnjeg depozitorija i drugih osoba koje se često nazovu operateri računa. ${ }^{19} \mathrm{U}$ netransparentnom sustavu središnjem depozitoriju nisu poznati krajnji ulagatelji, već se oni mogu identificirati samo na razini relevantnog posrednika. ${ }^{20}$ Postoje i sustavi koji su miješani, i to na način da čak i ako je riječ o transparentnom sustavu, on to prestaje biti prelaskom granice, odnosno kada se radi o transakciji s inozemnim elementom. ${ }^{21}$

Ako zamislimo primjer jedne takve transakcije koja involvira nekoliko posrednika preko triju jurisdikcija, vidljivo je na koji se način mijenja i koncept zakonitog imatelja. Uzmimo da neko dioničko društvo, izdavatelj iz UK-a emitira dionice i da je to izdanje upisano/pohranjeno u CREST koji je središnji depozitorij UK-a te da neka banka UK-a kao članica CREST-a upiše prvo te dionice "na sebe“. Očekivano, tu je mjerodavno pravo UK-a. Također je moguće da dio tog porftelja dionica stekne, primjerice, francuska banka. Ako je ugovor između engleske i francuske banke podvrgnut pravu UK-a, francuska banka imat će položaj beneficijalnog, a engleska banka nominalnog „vlasnika“ u skladu s engleskim konceptom trusta. No francuskoj banci koja je stekla

\footnotetext{
$16 \mathrm{U}$ izborniku: „The rights and property interest of an entitlement holder with respect to a financial asset held through a securities intermediary" (UCC § 8-102(a)(17)).

${ }_{17}$ Ulagatelj koji se nalazi na kraju lanca ima to pravo u odnosu na relevantnog posrednika, ali ne i $u$ odnosu na druge posrednike $u$ lancu. U slučaju da je posrednik insolventan imatelj računa, on je zaštićen jer mu pravo na sigurnost jamči da će vrijednosni papiri koje drži posrednik biti odvojeni od stečajne mase toga istog posrednika.

18 UNIDROIT-ov vodič.

19 Riječ je, primjerice, o investicijskim društvima koja održavaju izravne odnose s ulagateljima.

20 UNIDROIT-ov vodič, 25, par. 52.

${ }^{21}$ UNIDROIT-ov vodič, par. 53.
} 
određen broj dionica tog izdavatelja može se obratiti njemačka banka koja opet kao posrednik od francuske banke želi steći dio tih dionica za svog klijenta - njemački investicijski fond. Ako taj ugovor bude podvrgnut francuskom pravu, punopravni „vlasnik“ tih dionica bit će njemačka banka u skladu s francuskim pravom kao mjerodavnim pravom. Nadalje, u odnosu njemačke banke i njemačkoga investicijskog fonda bit će mjerodavno njemačko pravo, što će opet dovesti do promjene koncepta vlasništva koje se „dijeli“ između njemačke banke i njemačkoga investicijskog fonda, pričemu je ono jednako alikvotnom dijelu fungibilnog poola vrijednosnih papira upisanih u njemački središnji depozitorij..$^{22}$

\section{HRVATSKO PRAVO}

Hrvatski je zakonodavac od samoga uvođenja tržišta kapitala izrijekom uredio vlasništvo nad vrijednosnim papirima, prijenos vlasništva te račun nematerijaliziranih vrijednosnih papira još od 1996. godine kada je donesen Zakon o izdavanju i prometu vrijednosnim papirima. ${ }^{23} \mathrm{U}$ njemu je bilo propisano da vlasnik vrijednosnih papira ima račun vrijednosnih papira kod središnje depozitarne agencije, a vlasnikom nematerijaliziranoga vrijednosnog papira smatrao se vlasnik računa kod središnje depozitarne agencije na kojem je ubilježen vrijednosni papir. Takvo se izravno uređenje nastavilo i dalje definiranjem pojmova računa nematerijaliziranoga vrijednosnog papira, komu pripada pravo iz vrijednosnog papira, vlasništva nematerijaliziranih vrijednosnih papira, pa čak i založnog prava na nematerijaliziranim vrijednosnim papirima. ${ }^{24}$ Dakle, hrvatski je zakonodavac odmah otpočetka odlučio da će središnji depozitorij ujedno biti i registar "vlasništva“ vrijednosnih papira. ${ }^{25}$ No, komparativno gledano, funkcija upisnika kao registra "vlasništva“ nije nužna funkcija središnjeg depozitorija ${ }^{26}$, između ostalog, zbog prevladavajuće omnibus strukture računa u sre-

\footnotetext{
22 Primjerice, certifikat koji glasi na određen broj vrijednosnih papira ima u posjedu za sve ulagatelje njemački CSD. Krajnji ulagatelji dijele „vlasništvo“ nad tim zbirom vrijednosnih papira u skladu sa svojim alikvotnim dijelom s bankom skrbnicom - posrednicom koja je članica sudionica CSD-a. Van der Elst, Lafarre 2019, 117.

${ }^{23}$ V. čl. 81. -83. i 93. - 97. Zakona o izdavanju i prometu vrijednosnim papirima, NN, br. 107/95, 142/98 i $87 / 00$.

${ }^{24}$ V. čl. 125. -130. Zakona o tržištu vrijednosnih papira, NN, br. 84/02 i 138/06.

${ }_{25} \mathrm{~K}$ tomu, u RH je otpočetka postavljena vrlo široka obveza dematerijalizacije vrijednosnih papira prema kojoj su gotovo sva dionička društva osnovana u RH svoje dionice trebala dematerijalizirati i prenijeti u središnji depozitorij.

${ }^{26}$ U EU-u Češka, Estonija i Poljska nemaju takav sustav prema kojem bi središnji depozitorij bio jedini ili primarni registar podataka o vlasništvu nad vrijednosnim papirima, ali se podatci izmjenjuju $i$ sravnjuju s članovima CSD-a, dok Švicarska, Danska, Irska, Luksemburg i Rumunjska imaju CSD-ove koji uopće ne sravnjuju podatke s članovima. Vidi, The registration of securities holders, ECSDA, 2016, 23., dostupno na https://ecsda.eu/wp-content/uploads/2016_07_19_ECSDA_Registration_Report.pdf (10. 9. 2020.).
} 
dišnjim depozitorijima svojstvenima upravo neizravnim sustavima u kojima središnji depozitorij ne zna (a i ne mora znati) tko je krajnji vlasnik vrijednosnih papira. U tim slučajevima središnji depozitorij, kao i njegovi sudionici, redovito usklađuje svoje evidencije s evidencijama nacionalnog registra u koje se upisuje vlasništvo nad vrijednosnim papirima.

Donošenjem ZTK-a 2018. godine ${ }^{27}$ otišlo se korak dalje u preciziranju pojma zakonitog imatelja vrijednosnog papira. Prema čl. 528., st. 1. ZTK-a zakoniti je imatelj nematerijaliziranog vrijednosnog papira „subjekt kojem pripada tražbina odnosno pravo iz nematerijaliziranoga vrijednosnog papira“. ${ }^{28}$ Također je u st. 2. propisano da se "nematerijalizirani vrijednosni papiri vode na računu kod središnjeg depozitorija koji glasi na ime njihova zakonitog imatelja“. No, u st. 4. istog članka propisano je da se, iznimno od odredbe stavka 2. istoga članka, nematerijalizirani vrijednosni papiri mogu voditi na računu kod središnjeg depozitorija koji ne glasi na ime njihova zakonitog imatelja, nego osobe koja na temelju posebnog, posrednog ili neposrednog odnosa sa zakonitim imateljem (skrbnik, povjerenik, zastupnik ili netko treći) za zakonitog imatelja drži te vrijednosne papire.

Tom je odredbom ZTK potpuno promijenio dosadašnji koncept zakonitoga imatelja nematerijaliziranoga vrijednosnog papira. U prijašnjoj inačici ZTK-a zakonitim se imateljem nematerijaliziranoga vrijednosnog papira smatrala ponajprije osoba na čije ime glasi račun nematerijaliziranih vrijednosnih papira u središnjem depozitoriju na kojem je ubilježen nematerijalizirani vrijednosni papir te je bilo propisano da potraživanje, tj. pravo iz nematerijaliziranoga vrijednosnog papira pripada njegovu zakonitom imatelju. ${ }^{29} \mathrm{~S}$ obzirom na to da bi se zakonitim imateljem nematerijaliziranoga vrijednosnog papira trebao smatrati ponajprije subjekt kojem pripada potraživanje, odnosno pravo iz toga papira, sada je to jasno izrečeno. ${ }^{30}$

lako se u pravilu nematerijalizirani vrijednosni papiri vode na računu kod središnjeg depozitorija koji glasi na njihova zakonitoga imatelja, to pravilo ima i iznimku. $\mathrm{Na}$ ime, zakoniti imatelj nematerijaliziranoga vrijednosnog papira ne mora nužno biti osoba na čije ime glasi račun nematerijaliziranih vrijednosnih papira otvoren u središnjem depozitoriju. To osobito vrijedi za slučajeve skrbništva, zastupništva ili povjereništva, gdje netko treći drži vrijednosne papire za zakonitoga imatelja, a često $\mathrm{i}$ ostvaruje prava iz nematerijaliziranoga vrijednosnog papira u ime i za račun zakonitoga imatelja ili samo za račun zakonitoga imatelja, a na temelju posebnog odnosa

\footnotetext{
27 Zakon o tržištu kapitala, NN, br. 65/18.

${ }_{28}$ Dodatno, prema st. 3. istog članka, ako su vrijednosni papiri upisani na račun bez valjane pravne osnove ili ako je ta osnova otpala, subjekt na čije ime glasi račun kod središnjeg depozitorija nije zakoniti imatelj upisanih vrijednosnih papira, osim ako je pri stjecanju postupao u dobroj vjeri.

29 Derenčinović Ruk 2019, 185.

30 Derenčinović Ruk 2019, 185
} 
sa zakonitim imateljem (ugovor o skrbništvu, ugovor o povjereništvu, zastupnički odnos roditelja i djeteta i sl.). Takvi odnosi namjerno nisu pobrojeni u ZTK-u jer u praksi ili stvarnom životu mogu biti različiti. Osim toga, ti odnosi mogu biti posredni i neposredni, što je vidljivo baš na primjeru skrbničkih lanaca. ${ }^{31}$

Slijedom navedenog, proizlazi da se RH koristi izravnim modelom držanja vrijednosnih papira (poznat i kao transparentni model) te samim time pripada skupini zemalja s potpuno segregiranim tržištem. ${ }^{32}$ Taj se model koristi i u nordijskim zemljama (Finska i Norveška), Grčkoj, Turskoj, Malti, Bugarskoj, Bosni i Hercegovini, Crnoj Cori, Makedoniji, Srbiji i Sloveniji, a izvan Europe u Kini i Brazilu. ${ }^{33}$ Kod takva čistog transparentnog modela računi krajnjih ulagatelja otvaraju se na razini depozitorija, a banke koje se bave uslugama vezanima uz vrijednosne papire (primjerice skrbništvo) ne održavaju račune krajnjih ulagatelja, već samo upravljaju onima koje održava depozitorij (pod posebnim pravnim i operativnim okvirom). Kako je jedna od najvažnijih zadaća središnjeg depozitorija ipak namira, a uređena je Uredbom (EU) br. 909/2014 Europskog parlamenta i Vijeća od 23. srpnja 2014. o poboljšanju namire vrijednosnih papira u Europskoj uniji i o središnjim depozitorijima vrijednosnih papira te izmjeni direktiva 98/26/EZ i 2014/65/EU te Uredbe (EU) br. 236/2012 ${ }^{34}$ (dalje u tekstu: Uredba CSDR), pri usklađivanju ZTK-a s navedenom uredbom razmatrana su pitanja široko postavljene obveze dematerijalizacije, načina držanja vrijednosnih papira, pa čak i eventualne promjene postojećega izravnog modela držanja u neizravni, no kako se postojeći model pokazao u praksi kao kvalitetan, funkcionalan i učinkovit, nastojalo se spriječiti velike troškove prelaska na novi model.

\footnotetext{
${ }_{31}$ Primjerice, u središnjem depozitoriju u $\mathrm{RH}$ račun nematerijaliziranih vrijednosnih papira može glasiti na skrbnika (koji nije zakoniti imatelj nematerijaliziranih vrijednosnih papira ubilježenih na tom računu), koji drži te vrijednosne papire za skrbnika iz Austrije, a taj opet za globalnog skrbnika iz New Yorka, a potonji za skrbnika iz Hong Konga koji, pak, jedini ima izravnu vezu sa zakonitim imateljem i zna tko je on. U tom slučaju zakoniti imatelj nematerijaliziranoga vrijednosnog papira, dakle, nije nijedan od skrbnika ili podskrbnika u tom lancu, nego je to onaj subjekt koji sa skrbnikom ima poseban, neposredni odnos i za čiji račun skrbnik ostvaruje prava iz nematerijaliziranoga vrijednosnog papira. Zakoniti imatelj s ostalim skrbnicima/podskrbnicima u lancu skrbništva ima tek posredni odnos, upravo preko svoga inicijalnog skrbnika. Derenčinović Ruk 2019, 186.

${ }^{32}$ Kod segregiranih tržišta središnji depozitoriji CSD-ova nude posebnu vrstu računa koji sudionicima CSD-a omogućuju da segregiraju vrijednosne papire zasebnih klijenata / krajnjih ulagatelja, a CSD ima izravan pristup informacijama o identitetu tih pojedinaca / krajnjih ulagatelja. Uz to, uporaba odvojenih računa obvezujuća je za domaće sudionike i/ili ulagatelje, a katkad i za sve financijske instrumente. Account segregation practices at European CSDs, ECSDA, 2015, 3., dostupno na https://ecsda. eu/wp-content/uploads/2015_10_13_ECSDA_Segregation_Report.pdf (15. 9. 2020.).

${ }_{33}$ V. Account segregation practices at European CSDs, 3. i dalje. Prema podatcima ECSDA-a, član kojega je 41 depozitorij, postoje još i hibridni sustavi koji imaju mogućnost otvaranja individualnih računa krajnjih ulagatelja - Cipar, Češka, Danska, Estonija, Island, Rumunjska, Švedska, Slovačka, UK.

34 Uredba (EU) br. 909/2014 Europskog parlamenta i Vijeća od 23. srpnja 2014. o poboljšanju namire vrijednosnih papira u Europskoj uniji i o središnjim depozitorijima vrijednosnih papira te izmjeni direktiva 98/26/EZ i 2014/65/EU te Uredbe (EU) br. 236/2012, SL L 257, 28. 8. 2014.
} 
Dakle, hrvatski je zakonodavac u novom ZTK-u, kojim se uređuje provedba Uredbe CSDR odlučio da središnji depozitorij sa sjedištem u RH i dalje ostane i upisnik vrijednosnih papira. Pitanje namire, držanja vrijednosnih papira i njihova evidentiranja u nematerijaliziranom obliku na razini EU-a nije bilo uređeno do stupanja na snagu Uredbe CSDR. Sada je situacija bitno promijenjena te su sva pitanja vezana uz organizaciju i način rada središnjih depozitorija u EU-u vrlo detaljno uređena..$^{35}$ Uredba CSDR utvrđuje jedinstvene zahtjeve za namiru u EU-u i pravila za organizaciju i postupanje središnjih depozitorija te pritom definira nematerijalizirani oblik vođenja vrijednosnih papira u smislu elektroničkih zapisa, bilo da su vrijednosni papiri inicijalno izdani u nematerijaliziranom obliku bilo da su imobilizirani. U potonjem slučaju riječ je o tome da su vrijednosni papiri izdani kao isprave, a onda pohranjeni kod središnjeg depozitorija i evidentirani kao elektronički zapis pa se dalje vode u takvu obliku, ali isprava i dalje postoji. ${ }^{36}$ Uredba CSDR ne sadržava izričitu obvezu da središnji depozitorij mora ponuditi otvaranje direktnih računa krajnjim ulagateljima u svom sustavu. Središnji depozitorij mora individualne i omnibus račune ponuditi svojim članovima sudionicima, a sudionici ih moraju ponuditi svojim klijentima. ${ }^{37}$ To znači da je Uredba CSDR kompatibilna s izravnim i neizravnim modelom držanja vrijednosnih papira, što znači da se u njezinoj implementaciji moglo promijeniti postojeći izravni model kao i prijeći na neizravni da je to bila volja zakonodavca.

Navedeno određenje pojma zakonitog imatelja nematerijaliziranoga vrijednosnog papira i kategorizacija hrvatskog sustava u izravne modele te daljnja razrada pita-

\footnotetext{
35 Riječ je, u ovom trenutku, o Uredbi CSDR i sljedećim uredbama: Delegirana uredba 2017/389 o dopuni Uredbe (vezano uz parametre za izračun novčanih kazni za neuspjele namire i djelatnosti CSDova), Delegirana uredba 2017/390 o dopuni Uredbe (bonitetni zahtjevi), Delegirana uredba 2017/391 o dopuni Uredbe (tehnički standardi vezano uz internalizirane namire), Delegirana uredba 2017/392 0 dopuni Uredbe (vezano uz regulatorne tehničke standarde, odobrenje za rad te nadzorne i operativne zahtjeve), Delegirana uredba 2018/1229 o dopuni Uredbe (vezano uz regulatorne tehničke standarde o disciplini namire), Provedbena uredba 2017/393 u skladu s Uredbom (vezano uz internalizirane namire), Provedbena uredba 2017/394 u skladu s Uredbom (vezano uz razne standarde itd.); kao i Smjernicama ESMA-e: Smjernice - Suradnja tijela u skladu s člancima 17. i 23. Uredbe od 28. 3. 2018., Smjernice o postupku izračuna pokazatelja za određivanje velikog značaja CSD-a za državu članicu domaćina od 28. 3. 2018., Smjernice o postupku izračuna pokazatelja za određivanje najvažnijih valuta u kojima se namira izvršava od 28. 3. 2018., Smjernice - Pravila i postupci u slučaju neispunjavanja obveza sudionika CSD-ova od 8. 6. 2017., Smjernice - Pristup središnjeg depozitorija vrijednosnih papira (CSD) transakcijskim unosima CCP-ova $i$ mjesta trgovanja od 8. 6. 2017., Smjernice o izvješćivanju o internaliziranim namirama u skladu s člankom 9. CSDR-a od 30. 4. 2019. te Questions and Answers - Implementation of the Regulation (EU) No 909/2014 on improving securities settlement in the EU and on central securities depositories, dostupno na https://www. esma.europa.eu/sites/default/files/library/esma70-708036281-2_csdr_qas.pdf (8. 9. 2020.).

${ }_{36}$ Uredba CSDR također otvara tržište EU-a i omogućuje da bilo koji središnji depozitorij koji svoje sjedište ima na području EU-a te je licenciran prema Uredbi CSDR može svoje usluge pružati u bilo kojoj državi članici, ali i središnji depozitoriji iz trećih zemalja kada su njihovi pravni i nadzorni okviri priznati kao jednakovrijedni Uredbi CSDR.

37 V. čl. 38., st. 5. Uredbe CSDR i recital 42. Uredbe CSDR.
} 
nja vezanih uz obavljanje namire, naravno, ne rješavaju problem određivanja mjerodavnog prava u situaciji kada se vrijednosni papiri drže putem posrednika. No, osim što se postavlja pitanje kojem se pravu podvrgava utvrđenje pojma zakonitog imatelja („vlasnika“) vrijednosnog papira, podredno se postavlja pitanje koje radnje treba poduzeti da bi se to pravo valjano steklo, i to ne samo radi stjecanja "vlasništva" već i pri kreiranju (stvarnopravnog) osiguranja tražbine koje se zbog svog erga omnes učinka može isticati npr. prema stečajnoj masi sudionika namire nad kojim je otvoren stečajni postupak.

Hrvatsko pravo tržišta kapitala sadržava odgovore na ta pitanja u vidu kolizijskopravnih propisa. Navedena rješenja crpe se iz spomenute Uredbe CSDR i dviju direktiva od kojih je jedna relevantna za financijsko osiguranje ${ }^{38}$, a druga za konačnost namire (Direktiva o konačnosti namire ${ }^{39}$ ). Dalje se upućuje samo na opće kolizijsko pravilo s obzirom na to da se ono izravno tiče računa nematerijaliziranih vrijednosnih papira koji je ponajprije bitan za određenje pojma zakonitog imatelja odnosno „vlasnika“.

Opće kolizijsko pravilo sadržano je u čl. 563., st. 3. ZTK-a i ono glasi: „Ne dovodeći u pitanje odredbe članka 48. CSDR Uredbe, na račun nematerijaliziranih vrijednosnih papira primjenjuje se pravo države u kojoj je sjedište središnjeg depozitorija u kojem je taj račun otvoren. ${ }^{40} \mathrm{U}$ idućem stavku 4. istog članka, ZTK sadržava i pravilo kojim podvrgava primjeni pojedine aspekte držanja vrijednosnih papira posebnim kolizijskim pravilima. Tako je predviđeno da „iznimno od odredbe članka 48. CSDR Uredbe, na račune vrijednosnih papira na kojima je zasnovano financijsko osiguranje u smislu zakona kojim se uređuje financijsko osiguranje te na prava i obveze koje proizlaze iz sudjelovanja u sustavu namire u smislu zakona kojim se uređuje konačnost namire u platnim sustavima i sustavima za namiru financijskih instrumenata, primjenjuju se odredbe tih zakona“.

Vraćajući se na opće kolizijsko pravilo, postavlja se pitanje što u toj odredbi znači dio "ne dovodeći u pitanje odredbe čl. 48. CSDR Uredbe“. Prije svega, treba reći da se uređenjem sadržanim u čl. 563., st. 3. ZTK-a, zbog povezivanja europskih tržišta i subjekata koji na njima djeluju te se isprepleću u svojim vezama i odnosima, a što

${ }_{38}$ Direktiva 2002/47/EZ Europskog parlamenta i Vijeća od 6. lipnja 2002. o financijskom kolateralu, O] L 168, 27. 6. 2002., str. 43-50 (u međuvremenu izmijenjena dvjema direktivama: Direktivom 2009/44/ EC, SL L 146, str. 37,

od 10. 6. 2009. i Direktivom 2014/59/EU, SL L 173, str. 190, od 12. 6. 2014.).

39 Direktiva 98/26/EZ Europskog parlamenta i Vijeća od 19. svibnja 1998. o konačnosti namire u platnim sustavima i sustavima za namiru vrijednosnih papira, SL L 166, 11. 6. 1998., str. 45-50. U međuvremenu je izmijenjena s nekoliko direktiva, pri čemu odredba u kojoj je sadržano kolizijsko pravilo nije izmijenjena (čl. 9., st. 2.). Konsolidirana verzija dostupna je na https://eur-lex.europa.eu/ legal-content/EN/TXT/?uri=CELEX\%3A01998Lo026-20190627 (28. 1. 2021.).

40 Pristup bi se mogao nazvati lex loci depositorium. 
čini jedan od osnovnih postulata Uredbe CSDR, uvodi međunarodno priznat pristup određivanja mjerodavnog prava, tzv. PRIMA (Place of the Relevant Intermediary Approach) pristup. Taj pristup katkad se naziva i PRACA pristup. ${ }^{41}$ Naime, dok je prema PRIMA pristupu važno identificirati mjesto, locus relevantnog posrednika, za PRACA pristup to nije dovoljno, već je nužno utvrditi, odnosno locirati i račun vrijednosnih papira koji vodi odnosni posrednik. Pritom se taj račun uvijek vodi pri nekom upisniku, odnosno središnjem depozitoriju. No računom se može upravljati i iz drugog mjesta, različita od mjesta gdje se nalazi depozitorij. Stoga, iako je zapravo riječ o tome da se na račun nematerijaliziranih vrijednosnih papira primjenjuje pravo države u kojoj je sjedište središnjeg depozitorija u kojem je taj račun otvoren, iz daljnjeg teksta vidjet ćemo da to može biti i pravo koje je dogovoreno među ugovornim stranama.

Kada ZTK navedeno temeljno kolizijsko pravilo podvrgava primjeni odredaba članka 48. Uredbe CSDR, riječ je o tome da čl. 48., st. 3. Uredbe CSDR spominje veze središnjih depozitorija ${ }^{42}$ (tzv. CSD link) te nalaže da u slučaju postojanja te veze, nju mora poduprijeti odgovarajući ugovor u kojem se uređuju prava i obveze povezanih središnjih depozitorija i, po potrebi, njegovih sudionika. U tom će ugovoru biti potrebno nedvosmisleno odrediti mjerodavno pravo koje će uređivati sve aspekte djelovanja te veze. Kao zaključak nameće se da u slučaju veza središnjih depozitorija ne mora nužno biti primijenjeno pravo države u kojoj je sjedište depozitorija u kojem je račun otvoren, već središnji depozitoriji primjenu mjerodavnog prava samostalno uređuju ugovorom. Navedeno treba razumjeti kroz prizmu Uredbe CSDR koja omogućava slobodu pružanja usluga središnjim depozitorijima u svim državama članicama, uspostavljanje njihovih veza ${ }^{43}$ te pristup izdavatelja vrijednosnog papira bilo kojemu središnjem depozitoriju s poslovnim nastanom u državi članici.

Primjer takve CSD veze iz hrvatske prakse tržišta kapitala bio bi sljedeći. CSD vezu hrvatski središnji depozitorij (dalje u tekstu: SKDD) uspostavio je s Oesterreichische Kontrollbank AC (dalje u tekstu: OeKB), koja je austrijski središnji depozitorij, i to za certifikate koje izdaje austrijska Erste banka. Riječ je o jednostavnu linku kod kojeg SKDD otvara omnibus račun u sustavu OeKB-a za ulagatelje $\mathrm{RH}$, dok se podatci o po-

${ }^{41}$ Kunda 2011, 315.

${ }_{42}$ Navedeni pojam objašnjen je u čl. 2., t. 29. Uredbe CSDR: „veza CSD-ova” znači aranžman između CSD-ova na temelju kojeg jedan CSD postaje sudionik u sustavu za namiru vrijednosnih papira drugog CSD-a kako bi se olakšao prijenos vrijednosnih papira od sudionika potonjeg CSD-a do sudionika prethodnog CSD-a ili dogovor prema kojem CSD pristupa drugom CSD-u neizravno preko posrednika. Veze CSD-ova uključuju standardne veze, prilagođene veze, neizravne veze te interoperabilne veze. Najjednostavnije rečeno, ta veza služi da jedan CSD otvori račun kod drugog CSD-a za potrebe vođenja računa za ulagatelje iz svoje države. Npr. SKDD iz RH koji pri austrijskom CSD-u otvori zbirni račun za RH ulagatelje, primjerice, imatelje Erste certifikata. Veza može biti i naprednija pa da putem nje CSD-ovi rade tzv. rekoncilijacije podataka. Najviša je razina veze razina interoperabilnosti. Imaju je Clearstream i Euroclear, koji su time stvorili zajednički sustav.

${ }^{43}$ Engl. CSD Links (članak 48. CSDR-a). 
jedinačnim ulagateljima vode u sustavu SKDD-a. Transformacija koncepta „vlasništva" vidljiva je i u ovom primjeru. Podatci o certifikatima čiji su „vlasnici“ ulagatelji iz RH zabilježeni su izravno na računima ulagatelja u SKDD-u, međutim sami certifikati izdani su u Austriji i ubilježeni pri OeKB-u, odnosno austrijskome središnjem depozitoriju. Da bi se omogućilo trgovanje certifikatima na Zagrebačkoj burzi, SKDD otvara zbirni račun u OeKB-u na kojem se nalaze svi izdani certifikati. Tim zbirnim računom u sustavu OeKB-a administrira SKDD za ulagatelje $\mathrm{RH}$. Na taj zbirni račun primjenjuje se austrijsko pravo i koncept "vlasništva“ koji je predviđen austrijskim pravom, za razliku od hrvatskog prema kojem krajnji ulagatelj ima izravno i nedjeljivo pravo nad vrijednosnim papirima. ${ }^{44}$

S obzirom na postojanje posebnih kolizijskopravnih rješenja, za različita pitanja povezana s nematerijaliziranim vrijednosnim papirima te mogućnost da dođe do izražaja i autonomija volje središnjih depozitorija, konkretan odabir mjerodavnog prava i dalje je prilično nepredvidiv. Stoga Uredba CSDR u svojoj preambuli i navodi: „U pogledu sve većeg prekograničnog držanja i prijenosa vrijednosnih papira koji su poboljšani ovom Uredbom, vrlo je hitno i važno uspostaviti jasna pravila o pravu primjenjivom na aspekte vlasništva u odnosu na vrijednosne papire koji se drže na računima koje vode CSD-ovi. Unatoč tome, to je horizontalno pitanje koje je izvan područja primjene ove Uredbe te bi se ono moglo rješavati budućim zakonodavnim aktom Unije..$^{45}$

\section{UTJECA] BC TEHNOLOGIJE NA VOĐENJE UPISNIKA I POSREDNO DRŽANJE DIONICA}

Iz prethodnih je izlaganja vidljivo da kod posrednog držanja vrijednosnih papira te zbog globalne naravi tržišta kapitala pitanje mjerodavnog prava ostaje još uvijek nedovoljno predvidivo unatoč harmonizacijskim naporima. No, primjena BC/DLT tehnologija predvidivo donosi velike promjene upravo u načinu držanja dionica te moguću promjenu i načina upisivanja "vlasništva" nad dionicama s obzirom na to da je BC/DLT tehnologiji imanentno tzv. distribuirano knjiženje. ESMA, ali i drugi krovni regulatori financijskog tržišta, nalazi brojne prednosti primjene tih tehnologija pri

\footnotetext{
${ }^{44}$ Austrijsko pravo ima model sličan njemačkom, osim u slučaju suvlasničkih računa gdje su oni eksplicitno označeni kao takvi i odabrani od krajnjeg ulagatelja.

${ }_{45}$ V. recital br. 57 Uredbe CSDR. Također, odredbečl. 48. Uredbe CSDR u slučaju veza CSD-ova određuju da prije uspostave veze CSD-ova te neprekidno nakon uspostave veze CSD-ova svi dotični CSD-ovi utvrđuju, procjenjuju, prate i upravljaju svim potencijalnim izvorima rizika za sebe i za svoje sudionike koji proizlaze iz veze CSD-ova i poduzimaju odgovarajuće mjere za njihovo smanjenje (st. 1.). Prema st. 3. „(...) Vezu podupire odgovarajući ugovor u kojem se navode odnosna prava i obveze povezanih CSD-ova i, po potrebi, CSD-ovih sudionika. Ugovor s implikacijama sukoba nadležnosti predviđa nedvosmisleni izbor prava koje uređuje sve aspekte djelovanja veze."
} 
trgovanju vrijednosnim papirima. ${ }^{46}$ Europska komisija (dalje u tekstu: EK) također promiče DLT tehnologiju i potiče istraživanje njezine primjene u financijskom sektoru, uključujući i tržište vrijednosnih papira. ${ }^{47}$ Neke od prednosti koje se ističu u primjeni DLT-a odnose se na smanjenje rizika manipulacije podatcima, jačanje povjerenja, pouzdanost pri kontroli transakcija i podataka, pojednostavnjeno držanje i prijenos vrijednosnih papira, učinkovitije posttrgovinske procese, mogućnost bržeg plasiranja vrijednosnih papira na tržište, poboljšano izvještavanje i nadzor, veću prilagodljivost i dostupnost te smanjene troškove. ${ }^{48}$

Preduvjet je primjene novih tehnologija prihvaćanje novoga regulatornog okvira radi uspostave pravne sigurnosti u provedbi poduzetih transakcija i njihovih učinaka. ${ }^{49}$ Stajalište je EK-a da bi u ovom trenutku bilo preuranjeno mijenjati regulatorni okvir EU-a s ciljem dopuštanja decentraliziranih platformi za koje nije potrebno ishoditi dozvole (engl. permissionless, decentralized platforms). ${ }^{50}$ Međutim, ako je riječ o platformama koje su ovlaštene i centralizirane, ali ujedno i distribuirane, koje više sliče postojećima, postoji potreba za regulatornom akcijom. U kreiranju regulatornog okvira nove infrastrukture financijskog tržišta često se kao okosnica spominju CPMI-IOSCO Principles for Financial Market Infrastructures (PFMIs) ${ }^{51}$, odredbe spomenute Direktive o konačnosti namire i Uredbe CSDR.

${ }^{46}$ European Securities and Markets Authority, The Distributed Ledger Technology Applied to Securities Markets. Dostupno na https://www.esma.europa.eu/sites/default/files/library/dlt_report_-_esma501121423017-285.pdf (10. 5. 2020.). European Central Bank, Advisory Croup on Market Infrastructures for Securities and Collateral, Potential use cases for innovative technologies in securities post-trading. Dostupno na https://www.ecb.europa.eu/paym/intro/publications/pdf/ecb.miptopical190111.en.pdf (10. 5. 2020.). Bank of International Settlements, On the future of securities settlement. Dostupno na https://www. bis.org/publ/qtrpdf/r_qt2003i.pdf (12. 5. 2020.). Committee on Payments and Market Infrastructures, Distributed ledger technology in payment, clearing and settlement. Dostupno na https://www.bis.org/cpmi/ $\mathrm{publ} / \mathrm{d} 157 . \mathrm{pdf}$ (10. 7. 2020.).

47 European Commission Consultation Document on an EU framework for markets in crypto-assets. Dostupno na https://ec.europa.eu/info/sites/info/files/business_economy_euro/banking_and_finance/documents/2019-crypto-assets-consultation-document_en.pdf (29. 4. 2020.).

${ }^{48}$ European Securities and Markets Authority, The Distributed Ledger Technology Applied to Securities Markets. Dostupno na https://www.esma.europa.eu/sites/default/files/library/dlt_report_-_esma501121423017-285.pdf (10. 5. 2020.).

49 Final report of the Expert Croup on Regulatory Obstacles to Financial Innovation: 30 recommendations on regulation, innovation and finance, 50. Dostupno na https://ec.europa.eu/info/publications/191113-report-expert-group-regulatory-obstaclesfinancial-innovation_en (1. 6. 2020.).

${ }_{50}$ European Commission Consultation Document on an EU framework for markets in crypto-assets, 30. Dostupno na https://ec.europa.eu/info/sites/info/files/business_economy_euro/banking_and_finance/ documents/2019-crypto-assets-consultation-document_en.pdf (29. 4. 2020.).

${ }^{51}$ Committee on Payment and Settlement Systems, Technical Committee of the International Organization of Securities Commissions, Principles for financial market infrastructures (CPMI PFMIs). Dostupno na https://www.bis.org/cpmi/publ/d101a.pdf (27. 8. 2020.). 
Jedno je od temeljnih pitanja vezano uz primjenu nove tehnologije može li se postojeći sustav vođenja upisnika prava nad vrijednosnim papirima transformirati u sustav koji će biti potpuno decentraliziran ili i dalje treba postojati središnje tijelo koje će nadzirati i upravljati cjelokupnim procesom. ${ }^{52}$ Ima autora ${ }^{53}$ koji tvrde da potpuna decentralizacija nije moguća, ako ni zbog čega drugog, onda zbog toga što mora postojati jedno središnje tijelo koje će upravljati rizicima, odnosno ono se mora moći identificirati, osobito ako je u pitanju rizik održivosti sustava (engl. system risk). Tvrdi se da se neke funkcije jednostavno ne mogu potpuno decentralizirati. Problem je to veći kada je u pitanju nadzor. Regulator bi teško mogao ostvarivati učinkovit nadzor nad decentraliziranom mrežom (sudionika transakcije) koja se proteže u više jurisdikcija izvan njegova regulatornog područja. Stoga se zagovara stajalište o postojanju jednog operatera koji će nadzirati primjenu DLT-a ${ }^{54}$, što govori u prilog tomu da bi postojeći središnji depozitoriji mogli nadograditi svoj sustav primjenjujući novu tehnologiju. Također, postojanje jednog operatera olakšava pronalaženje mjerodavnog prava. Dakle, taj operater morao bi moći obavljati barem funkciju upravitelja rizikom održivosti sustava te bi zbog toga morao moći provesti nadzor upravo nad onim aspektima sustava koji se odnose na rizik njegove održivosti.

U kontekstu distribuirane mreže to bi značilo da bi operater imao autonomiju kada je u pitanju dizajniranje, nadgledanje i upravljanje sistemskim protokolom pod kojim se podrazumijeva poseban softver (engl. system specific software). ${ }^{55} \mathrm{U}$ tom se smislu postavlja daljnje pitanje - trebaju li već postojeći CSD-ovi uvesti BC tehnologiju u primjenu? Prema trenutačnom stanju zakonodavstva u Europi, to je moguće samo ako su tokenizirani vrijednosni papiri izjednačeni s vrijednosnim papirima onako kako su definirani Uredbom CSDR. Pod tom pretpostavkom velika

\footnotetext{
52 Kritički o javnom, potpuno decentraliziranom blockchainu, v. Mik 2020, 164 i 168.

53 Garré, Voisin, Hay, Le Vesconte 2020, 7-8 i 10.

${ }^{54}$ Carré, Voisin, Hay, Le Vesconte 2020, 7-8 i 10, gdje ističu da postoje dva različita načina na koje bi se knjiga vrijednosnih papira mogla održavati na raspodijeljenoj (distribuiranoj) osnovi. Prvi je model "model distribuiranog zapisa" (engl. distributed record model) prema kojem operater zadržava punu odgovornost za provjeru valjanosti transakcija i jedini je izvor informacija u distribuiranoj mreži, dok prema drugom modelu koji se naziva "model distribuirane provjere valjanosti“ (engl. distributed validation model) sudionici mreže (ili jedan dio njih) drže/vode čvorove za provjeru valjanosti koji dijele funkciju provjere valjanosti prijenosa i održavanja glavne knjige u skladu sa sistemskim protokolom. Zagovornici DLT utemeljenih sustava često upućuju na to da distribuirana provjera valjanosti povećava „otpornost" sustava jer je riječ o distribuciji (raspodjeli) što dovodi do uklanjanja ili ublažavanja „kvara“ koji bi doveo do rušenja cijelog sustava. Prema modelu distribuirane provjere valjanosti, operater ne bi preuzeo odgovornost prema bilo kojem sudioniku koji je stranka u transakciji u slučaju kasne ili netočne namire. Konkretno, prema sustavu u kojem bi se različitim slojevima posredničkog lanca skrbnika odobrio pristup pojedinoj knjizi koju nadgleda operater sustava (što nazivamo „vertikalnom integracijom“), zahtjevi za operatera bili bi pretjerani. Dio njegove funkcije upravljanja rizikom bio bi uspostavljanje okvira odgovornosti gdje svaki čvor validatora preuzima specifične odgovornosti prema stranama u transakciji.
}

55 Garré, Voisin, Hay, Le Vesconte 2020, 8. 
je vjerojatnost da bi tim DLT sustavom trebao upravljati CSD, što bi bilo u skladu s Uredbom CSDR.

Govoreći o BC tehnologiji, ona je dio DLT tehnologije. ${ }^{56}$ Pod pojmom BC-a podrazumijeva se decentralizirana baza podataka (tzv. distribuirana knjiga) koja djeluje $u$ mreži s više čvorova (engl. nodes), odnosno računala. U našem slučaju možemo uzeti za primjer prodaju dionice (koja može glasiti na izravnog ulagatelja ovisno o modelu, ali i na posrednika). Najprije se bitni elementi transakcije unose u podatkovni blok koji dobiva jedinstveni digitalni potpis (jedinstven za taj blok kao i za njegov sadržaj), nakon čega blok dobiva tzv. hash, koji konvertira tekst u tzv. string of bytes. Nakon toga se transakcija „oglašava“ na distribuiranoj mreži te slijedi njezina provjera koja se zasniva na unaprijed uglavljenom mehanizmu mrežnog konsenzusa. Ako je riječ o javnom BC-u, uobičajeno je da podatkovni blok potvrdi 51 \% sudionika mreže. Nakon potvrde novi se podatkovni blok pridodaje na postojeći podatkovni lanac, postaje neizmjenjiv (engl. immutable) i vidljiv svim članovima mreže. ${ }^{57}$ Svaki je blok na jedinstven način povezan sa sljedećim, a zapisan je na svim računalima na mreži, što je važan element njegove sigurnosti jer bi osoba koja bi pokušala zlonamjerno izmijeniti podatke u bloku morala to učiniti ne samo na razini jednoga podatkovnog bloka na jednom računalu, već na razini svih podatkovnih blokova u nizu (jer je tzv. hash prethodnog bloka ujedno početni hash idućeg bloka i tako redom), i to na svim računalima mreže za što je potrebna golema računalna snaga.

$\mathrm{BC}$ pohranjuje zapise svih transakcija koje su ikad izvršene na mreži, odnosno funkcionira po načelu trajnih neizbrisivih zapisa (engl. open ended) koji se samo nadodaju. Sažeto, u BC-u ne postoji središnji zapis koji bi jedini bio valjan, dakle sve su informacije dostupne na svakom „čvoru mreže“, odnosno ne dolazi do njihova ujedinjavanja samo na jednom mjestu..$^{58} \mathrm{BC}$ može biti javni kada mu može svatko pristupiti i koristiti se njime za provođenje transakcije, odnosno privatni (ili poluprivatni) kada sustavu može pristupiti samo ograničen i unaprijed određen broj sudionika. To mogu biti, primjerice, privatni lanci između bankara ili osiguravatelja. Dalje se BC može dijeliti na one za koje „nije potrebna dozvola“ (engl. permissionless) i „odobrene"/"ovlaštene" (engl. permissioned), ovisno o tome tko može izvršavati transakcije i tko ih može provjeriti. Ako bilo tko može izvršavati i provjeravati transakcije, riječ je o BC-u „bez dozvole“. Ako se traži ovlaštenje za izvršavanje ili provjeru valjanosti transakcija, ili oboje, BC se naziva "ovlaštenim“.

Kako u BC-u ne postoji središnja točka kvara, a zbog postojanja većeg broja distribuiranih čvorova vrlo je teško istodobno ciljati većinu ili potpuno „razbiti“ cijelu mrežu,

\footnotetext{
${ }^{56}$ Više o temeljnim podjelama i tehnološkim obilježjima, umjesto svih v. Finck 2019, 14-16. De Filippi, Wright 2018, 33-57.

57 O pojmu immutability v. više kod Mik 2020, 171 i dalje.

${ }^{58}$ De Vauplane 2018, 94.
} 
$B C$ zahtijeva da nijedan operater ni u jednom trenutku ne drži više od polovice računalne snage lanca da bi se spriječila zlonamjerna izmjena podataka..$^{59} \mathrm{Ujedno,} \mathrm{sustav}$ mora biti u stanju zadržati svoju pouzdanost u slučaju da sudionik pošalje pogrešne ili zlonamjerne informacije kako bi zaobišao provjeru prijevarnog postupanja. ${ }^{60}$

Ako usporedimo BC model upisa podataka i onaj koji trenutačno provodi SKDD, upada u oči da se upisnik koji vodi SKDD temelji na modelu računa koji glasi na osobu, odnosno zakonitog imatelja, dok se u BC-u knjiži sama transakcija, stoga zapisi više nalikuju na kontinuum zbirke isprava. $U$ konvencionalnom modelu postoji središnje tijelo koje vodi upisnik (engl. legal ledger), dok se u BC-u podatci knjiže na sva računala u mreži. U konvencionalnom modelu vjerodostojnost podataka koji se upisuju verificira središnje tijelo, dok u BC-u zapis postaje vjerodostojan kada mreža transakciju "validira" mehanizmom konsenzusa. $U$ konvencionalnom modelu prijašnji se zapisi brišu, a u BC-u ostaju trajno dostupni „svima“. Upis i vođenje baze podataka o nematerijaliziranim vrijednosnim papirima ne zahtijevaju primjenu kriptografije, dok tokenizirani vrijednosni papiri moraju imati elemente kriptografije kao što su javni i privatni ključ, hash i sl.

$U$ vezi s time, CSD-ovi jesu glavni akteri za namiru, ali vode i upisnike vrijednosnih papira, pa je pitanje uvođenja BC-a kao načina vođenja upisnika vrijednosnih papira prirodno na njih adresirano. Kako prema postojećemu pravnom okviru biti izravni član nekog CSD-a podrazumijeva ispunjenje uvjeta koji se tiču pravnih, financijskih i operativnih zahtjeva (uključujući one navedene u Direktivi o konačnosti namire) kao rezultat toga, većina ulagatelja nije izravni član CSD-a, većdrži svoje vrijednosne papire putem posrednika.

To posljedično dovodi do toga da umjesto držanja vrijednosnih papira s pravima koja se izravno ostvaruju prema izdavatelju, ulagatelj stoji u odnosu s posrednikom, a gledano sa stajališta izdavatelja, oni u konačnici neće znati tko ostvaruje krajnji ekonomski interes iz toga vrijednosnog papira. ${ }^{61}$ Postoji niz razloga zbog čega i ulagateljima i izdavateljima odgovara da se vrijednosni papiri drže na taj način: olakšano se ulaže prekogranično, ulagatelji imaju koristi od usluga što ih nude posrednici, a izdavatelje se štiti od velika broja zahtjeva što bi ih mogli postavljati krajnji ulagatelji. BC tehnologija omogućava restauraciju (ili renesansu) izravna odnosa ula-

\footnotetext{
59 De Vauplane 2018, 95.

${ }^{60} \mathrm{~S}$ tom se svrhom protokol koristi kriptografskim sustavom temeljenim na decentraliziranom sustavu dokazivanja. Ovdje je potrebna visoka računska sposobnost koju pružaju tzv. miners. To su agenti čija je funkcija opskrba mreže računalnom snagom i omogućavanje ažuriranja decentralizirane baze podataka. Da bi ažurirali bazu podataka, „rudari“ moraju moći potvrditi nove „blokove“ dešifriranjem podataka (klasični kriptografski rad). Što je više „rudara“, to je teže dodijeliti dokaz o radu. Dakle, protokol može postati gotovo nepovrediv jer je konkurencija jaka na svakom čvoru mreže, tj. nijedna skupina "rudara“ ne postaje većina.

${ }^{61} \mathrm{O}$ toj problematici v. više kod Čulinović-Herc, Zubović 2018, 133-160.
} 
gatelja i izdavatelja, a utječe, naravno, i na povećanje transparentnosti. Sjetimo se samo kako je držanje određenog bloka dionica s pravom glasa u uvrštenom društvu okidač za obvezu objave tog podatka ${ }^{62}$, a ako je taj podatak dostupan svima preko $\mathrm{BC}-\mathrm{a}$, promijenit će se i paradigme potrebnih objava.

\section{PREMA ZAKLJUČKU}

Primjena BC-a/DLT-a svakako će utjecati na tržište usluga posrednika na tržištu kapitala. To je ujedno i najvažnija posljedica zbog koje se može očekivati da će tradicionalni posrednici prigrliti novu tehnologiju da ne bi izgubili utrku na rastućem tržištu kriptoimovine. Ima autora koji tvrde da to nikako ne znači nestanak posredničkih usluga, nego da će doći do njihove metamorfoze. ${ }^{63}$ Posrednici će jednostavno početi nuditi one posredničke usluge koje olakšavaju korisnicima primjenu same tehnologije, ili će u vrijeme dok još usporedno postoji konvencionalni model osiguravati interoperabilnost postojeće i nove tehnologije. Također, informacije na BC-u mogu biti dostupne, ali mogu zahtijevati određenu obradu, pa će rafiniranje podataka u skladu s potrebama klijenata biti nova tržišna niša za posrednike. S obzirom na to da se na tokenizirane vrijednosne papire u DLT-u prirodno mogu nadovezati pametni ugovori, i trgovina i namira mogu se odvijati bilateralno, bez posrednika. Mogući novi fokus posrednika mogao bi biti usmjeren na olakšavanje bilateralne trgovine i namire te osiguranje interoperabilnosti stare i nove tehnologije.

Tu se, naravno, postavlja i pitanje koegzistencije (sada već klasičnih) nematerijaliziranih vrijednosnih papira i tokeniziranih vrijednosnih papira koji formalno još uvijek nisu pravno izjednačeni. No i da jesu, niz pitanja otvara se u scenariju ako paralelno pravno postoje. Vrijedi li nematerijalizirana dionica društva koje kotira na burzi isto kao i tokenizirana dionica istog izdavatelja? Je li uopće riječ o istom tržištu? Kako će na sustav držanja tokeniziranih vrijednosnih papira utjecati činjenica da BC sustavi ne podupiru knjiženje po načelu terećenja ili knjiženja na račun i drugo.

Vraćajući se na naša početna pitanja, valja konstatirati da su vrijednosni papiri koji se "drže" putem BC-a prilično nepomirljivi s posrednim modelima držanja vrijednosnih papira. U BC-u pravni se odnosi ne grade na višerazinskim odnosima između ulagatelja i niza posrednika, već izravno između sudionika u lancu. BC je kompatibilniji s izravnim sustavom u kojem ulagatelji imaju izravna prava naspram izdavatelja. U tom smislu BC sliči nordijskom sustavu ${ }^{64}$ gdje ulagatelji zadržavaju izravnu vezu s izdavateljem, a posrednici nemaju pravnu poziciju u vrijednosnim papirima eviden-

\footnotetext{
62 V. više kod Čulinović-Herc, Zubović 2013, 37-81.

${ }_{63}$ Ceis 2018, 263-264.

${ }^{64} \mathrm{U}$ nekim nordijskim zemljama vrijednosni su papiri u obliku book entry, ali svaki vlasnik ima račun pri CSD-u i može izravno djelovati prema izdavatelju.
} 
tiranima u BC-u. Međutim, postoji jedna temeljna razlika u odnosu na nordijski sustav. U nordijskom sustavu postoji samo jedna glavna knjiga (engl. legal ledger) koja se vodi u središnjem depozitoriju (CSD), dok su u BC-u podatci upisani u distribuiranu knjigu bez CSD-a.

Ako se CDS-ovi budu profilirali kao mjesto primjene BC tehnologije, zbog straha od gubitka rastućeg tržišta kriptoimovine, na koje se sudionici transakcija mogu orijentirati, nužno će se postaviti pitanje tko će moći unutar tog sustava imati pristup novoj BC infrastrukturi. Trenutačni uvjeti, kao što je opisano, podrazumijevaju ispunjenje određenih kriterija za pristup sustavu, a taj se ograničeni pristup zagovara i u doktrini. ${ }^{65}$ To stajalište potkrepljuje se odredbama CSDR-a kojima se propisuje da CSD mora imati djelotvorna i jasno definirana pravila i postupke za upravljanje neispunjavanjem obveza jednog ili više njegovih sudionika (čl. 41., st. 1. CSDR-a) te je obvezan identificirati, nadzirati i upravljati rizicima koji mogu nastati njegovim operacijama (čl. 45., st. 6. CSDR-a).

Dakle, ostaje kao ključno pitanje kako pomiriti odnosno uskladiti postojeća regulatorna ograničenja (zahtjeve) s novim okolnostima i mogućnostima koje pruža nova tehnologija. Nekako se nameće shvaćanje da dizajn sustava treba biti takav da pristup njemu ne bude potpuno otvoren, odnosno da to bude sustav uz dozvolu te da bez obzira na sustav decentraliziranog knjiženja uvijek treba moći identificirati jedan središnji čvor, ako ni zbog čega drugog, onda radi identificiranja osobe koja upravlja sistemskim rizikom, što bi u modelu potpune decentralizacije bilo neutvrdivo. ${ }^{66}$

Što se tiče ispunjenja posebnih regulatornih uvjeta za pristup sustavu, taj će se kriterij morati pomno odmjeriti i usporediti s podudarnim kriterijima koji će se tražiti za tržište kriptoimovine, a taj bi segment uskoro trebao dobiti svoju pravnu regulaciju. Osim stidljivih i parcijalnih regulatornih zahvata nacionalnih zakonodavaca država članica EU-a, što odražava rastuću regulatornu kompeticiju u toj domeni ${ }^{67}$, Europska komisija u rujnu prošle godine izišla je s Prijedlogom uredbe kojom namjerava ure-

${ }_{65}$ Carré, Voisin, Hay, Le Vesconte 2020, 13.

${ }_{66}$ Garré, Voisin, Hay, Le Vesconte 2020, 8.

${ }_{67}$ Malta Digital Innovation Authority Bill, dostupno na https://parlament.mt/en/13th-leg/bills/biII-no-045-malta-digital-innovation-authority-bill/ (10. 9. 2020.). Code Monétaire et Financier, Les minibons (Articles L223-6 à L223-13), dostupno na https://www.legifrance.gouv.fr/codes/section_Ic/ LEGITEXTO00006072026/LEGISCTA000032468111/ (8. 9. 2020.). Le Plan d'Action pour la Croissance et la Transformation des Entreprises (PACTE), dostupno na https://www.economie.gouv.fr/files/files/2019/ PACTE_Juin2019/bro-a4-pacte.pdf (8. 9. 2020.). Projet de loi portant modification de la loi modifiée du 1er août 2001 concernant la circulation de titres, dostupno na http://legilux.public.lu/eli/etat/projet/pl/10486 (10. 9. 2020.). Entwurf eines Cesetzes zur Einführung von elektronischen Wertpapieren, dostupno na https://www.bmjv.de/SharedDocs/Cesetzgebungsverfahren/Dokumente/RegE_Einfuehrung_elektr_Wertpapiere.pdf?__blob=publicationFile\&v=3 (20.12. 2020.). 
diti tržište kriptoimovine, pri čemu je već po regulatornom stilu stala na stajalište da uređenje toga tržišta mora biti jedinstveno. ${ }^{68}$ No upada u oči da su financijski instrumenti izuzeti od polja primjene prema čl. 2., st. 1,. t. 2. Prijedloga navedene uredbe na način kako su definirani u čl. 4., st. 1., t. 15. Direktive 2014/65/EU69 tako da će ta „klasa“ kriptoimovine, čini se, slijediti svoj zasebni regulatorni put.

\section{LITERATURA}

1. Čulinović-Herc, E.; Zubović, A. (2013). (Ne)objavljivanje podataka o promjenama u korporativnoj strukturi uvrštenog dioničkog društva i utjecaj na prelazak kontrolnog praga - novi pojavni oblici držanja dionica ispod radara regulatora. Zbornik Pravnog fakulteta Sveučilišta u Rijeci, 1 (34), str. 37-81.

2. Čulinović-Herc, E.; Zubović, A. (2015). Tackling Empty Voting in EU-Shareholders' Rights Directive and Revised Transparency Directive. Croatian Yearbook of European Law and Policy, 11, str. 133-160.

3. De Filippi, P.; Wright, A. (2018). Blockchain and the Law-The Rule of Code. Harvard University Press.

4. De Vauplane, H. (2018). Blockchain and intermediated securities. National Insurance Producer Registry, 1, str. 94-103.

5. Derenčinović Ruk, M. (2019). Novi Zakon o tržištu kapitala, u: Miladin, P.; Giunio, M. (ur.). Zbornik 57. susreta pravnika - Opatija '19. Hrvatski savez udruga pravnika u gospodarstvu, Zagreb, str. 153-193.

6. Donald, D. C. (2011). Heart of Darkness: The Problem at the Core of the U.S. Proxy System and its Solution. Virginia Law \& Business Review, 6 (1), str. 41-100.

7. Finck, M. (2019). Blockchain Regulation and Covernance in Europe. Cambridge University Press.

8. Garré, B.; Voisin, M.; Hay, R.; Le Vesconte, S. (2020). A vision for regulated digital security infrastructure in Europe. Capital Markets Law Journal, 15 (3), str. 298-321. https://doi. $\operatorname{org} / 10.1093 / \mathrm{cmlj} / \mathrm{kmaa012}$.

9. Geis, G. S. (2018). Traceable Shares and Corporate Law. Northwestern University Law Review, 113 (2), str. 227-277.

10. Kunda, I. (2011). Ostvarivanje članskih prava u sustavu prekograničnog držanja dionica putem posrednika, u: Čulinović-Herc, E.; Jurić, D.; Žunić Kovačević, N. (ur.). Financiranje, upravljanje i restrukturiranje trgovačkih društva u doba recesije. Pravni fakultet u Rijeci, Rijeka, str. 303-336.

${ }_{68}$ Prijedlog Uredbe Europskog parlamenta i Vijeća o tržištima kriptoimovine i izmjeni Direktive (EU) 2019/1937, COM(2020) 593 final.

${ }^{69}$ Direktiva 2014/65/EU Europskog parlamenta i Vijeća od 15. svibnja 2014. o tržištu financijskih instrumenata i izmjeni Direktive 2002/92/EZ i Direktive 2011/61/EU, SL L 173, 12. 6. 2014. 
11. Markovinović, H.; Tepeš, N. (2011). Ostvarivanje prava glasa po dionicama u skrbništvu, u: Čulinović-Herc, E.; Jurić, D.; Žunić Kovačević, N. (ur.). Financiranje, upravljanje i restrukturiranje trgovačkih društva u doba recesije. Pravni fakultet u Rijeci, Rijeka, str. 339-377.

12. Mik, E. (2020). Blockchains - A Technology for Decentralized Marketplace, u: DiMatteo, L. A.; Cannarsa, M.; Poncibò, C. (eds.). The Cambridge Handbook of Smart Contracts, Blockchain Technology and Digital Platforms. Cambridge, str. 141-210.

13. Panisi, F.; Buckley, R. P.; Arner, D. (2019). Blockchain and Public Companies: A Revolution in Share Ownership Transparency, Proxy Voting and Corporate Governance?. Stanford Journal of Blockchain Law \& Policy, 2 (2), str. 189-220.

14. Van der Elst, C.; Lafarre, A. (2019). Blockchain and Smart Contracting for the Shareholder Community. European Business Organization Law Review, 20 (2), str. 111-137. DOI: 10.1007/ s40804-019-00136-0.

\section{Pravni izvori:}

1. Delegirana uredba Komisije (EU) $2017 / 389$ od 11. studenoga 2016. o dopuni Uredbe (EU) br. 909/2014 Europskog parlamenta i Vijeća u pogledu parametara za izračun novčanih kazni za neuspjele namire i djelatnosti CSD-ova u državi članici domaćinu, SL L 65, 10. 3. 2017.

2. Delegirana uredba Komisije (EU) $2017 / 390$ od 11. studenoga 2016. o dopuni Uredbe (EU) br. 909/2014 Europskog parlamenta i Vijeća u vezi s regulatornim tehničkim standardima o određenim bonitetnim zahtjevima za središnje depozitorije vrijednosnih papira i imenovane kreditne institucije koje pružaju pomoćne usluge bankovnog tipa, SL L 65, 10. 3. 2017.

3. Delegirana uredba Komisije (EU) $2017 / 391$ od 11. studenoga 2016. o dopuni Uredbe (EU) br. 909/2014 Europskog parlamenta i Vijeća u pogledu regulatornih tehničkih standarda kojima se dodatno određuje sadržaj izvješćivanja o internaliziranim namirama, SL L 65, 10. 3. 2017.

4. Delegirana uredba Komisije (EU) 2017/392 od 11. studenoga 2016. o dopuni Uredbe (EU) br. 909/2014 Europskog parlamenta i Vijeća u pogledu regulatornih tehničkih standarda povezanih sa zahtjevima za odobrenje za rad te nadzornim i operativnim zahtjevima za središnje depozitorije vrijednosnih papira, SL L 65, 10. 3. 2017.

5. Delegirana uredba Komisije (EU) 2018/1229 od 25. svibnja 2018. o dopuni Uredbe (EU) br. 909/2014 Europskog parlamenta i Vijeća u pogledu regulatornih tehničkih standarda o disciplini namire, SL L 230, 13. 9. 2018.

6. Direktiva 2002/47/EZ Europskog parlamenta i Vijeća od 6. lipnja 2002. o financijskom kolateralu, SL L 168, 27. 6. 2002.

7. Direktiva 2009/44/EZ Europskog parlamenta i Vijeća od 6. svibnja 2009. o izmjeni Direktive 98/26/EZ o konačnosti namire u platnim sustavima i sustavima za namiru vrijednosnih papira i Direktive 2002/47/EZ o ugovorima o financijskom kolateralu s obzirom na povezane sustave i kreditna potraživanja, SL L 146, 10. 6. 2009. 
8. Direktiva 2014/59/EU Europskog parlamenta i Vijeća od 15. svibnja 2014. o uspostavi okvira za oporavak i sanaciju kreditnih institucija i investicijskih društava te o izmjeni Direktive Vijeća 82/891/EEZ i direktiva 2001/24/EZ, 2002/47/EZ, 2004/25/EZ, 2005/56/ EZ, 2007/36/EZ, 2011/35/EU, 2012/30/EU i 2013/36/EU te uredbi (EU) br. 1093/2010 i (EU) br. 648/2012 Europskog parlamenta i Vijeća, SL L 173, 12. 6. 2014.

9. Direktiva 98/26/EZ Europskog parlamenta i Vijeća od 19. svibnja 1998. o konačnosti namire u platnim sustavima i sustavima za namiru vrijednosnih papira, SL L 166, 11. 6. 1998.

10. Direktiva 2014/65/EU Europskog parlamenta i Vijeća od 15. svibnja 2014. o tržištu financijskih instrumenata i izmjeni Direktive 2002/92/EZ i Direktive 2011/61/EU, SL L 173, 12. 6. 2014.

11. Prijedlog uredbe Europskog parlamenta i Vijeća o tržištima kriptoimovine i izmjeni Direktive (EU) 2019/1937, $\operatorname{COM(2020)} 593$ final.

12. Provedbena uredba Komisije (EU) 2017/393 od 11. studenoga 2016. o utvrđivanju provedbenih tehničkih standarda u pogledu predložaka i postupaka za izvješćivanje i prijenos informacija o internaliziranim namirama u skladu s Uredbom (EU) br. 909/2014 Europskog parlamenta i Vijeća, SL L 65, 10. 3. 2017., str. 116-144.

13. Provedbena uredba Komisije (EU) $2017 / 394$ od 11. studenoga 2016. o utvrđivanju provedbenih tehničkih standarda u vezi sa standardnim obrascima, predlošcima i postupcima za izdavanje odobrenja za rad, preispitivanje i ocjenu središnjih depozitorija vrijednosnih papira, za suradnju između tijela matičnih država članica i država članica domaćina, za savjetovanje s tijelima uključenima u izdavanje odobrenja za pružanje pomoćnih usluga bankovnog tipa, za pristup koji uključuje središnje depozitorije vrijednosnih papira, te u vezi s formatom evidencije koju moraju voditi središnji depozitoriji vrijednosnih papira u skladu s Uredbom (EU) br. 909/2014 Europskog parlamenta i Vijeća, SL L 65, 10. 3. 2017.

14. Securities Acts Amendments of 1975, Pub. L. 94-29, June 4, 1975.

15. Uredba (EU) br. 909/2014 Europskog parlamenta i Vijeća od 23. srpnja 2014. o poboljšanju namire vrijednosnih papira u Europskoj uniji i o središnjim depozitorijima vrijednosnih papira te izmjeni direktiva 98/26/EZ i 2014/65/EU te Uredbe (EU) br. 236/2012, SL L 257, 28. 8. 2014.

16. Zakon o izdavanju i prometu vrijednosnim papirima, NN 107/95, 142/98 i $87 / 00$.

17. Zakon o tržištu kapitala, NN 65/18, 17/20.

18. Zakon o tržištu vrijednosnih papira, NN 84/02 i 138/06.

\section{Mrežni izvori:}

1. Account segregation practices at European CSDs, ECSDA, 2015, https://ecsda.eu/wp-content/ uploads/2015_10_13_ECSDA_Segregation_Report.pdf (15. 9. 2020.).

2. Bank of International Settlements, On the future of securities settlement, https://www.bis. org/publ/qtrpdf/r_qt2003i.pdf (12. 5. 2020.).

3. Code Monétaire et Financier, Les minibons (Articles L223-6 à L223-13), https://www.legifrance. gouv.fr/codes/section_lc/LEGITEXTo0o006072026/LEGISCTA000032468111/ (8. 9. 2020.). 
4. Committee on Payment and Settlement Systems, Technical Committee of the International Organization of Securities Commissions, Principles for financial market infrastructures (CPMI PFMIs), https://www.bis.org/cpmi/publ/d101a.pdf (27. 8. 2020.).

5. Committee on Payments and Market Infrastructures, Distributed ledger technology in payment, clearing and settlement, https://www.bis.org/cpmi/publ/d157.pdf (10. 7. 2020.).

6. Convention of 5 July 2006 on the Law Applicable to Certain Rights in Respect of Securities held with an Intermediary (Haška konvencija o pravu mjerodavnom za vrijednosne papire koje drže posrednici), 5 July 2006., https://assets.hcch.net/docs/3afb8418-7eb7-4aoc-af85c4f35995bb8a.pdf (20. 5. 2020.).

7. Entwurf eines Cesetzes zur Einführung von elektronischen Wertpapieren, https://www.bmjv. de/SharedDocs/Cesetzgebungsverfahren/Dokumente/RegE_Einfuehrung_elektr_ Wertpapiere.pdf?__blob=publicationFile\&v=3 (20. 12. 2020.).

8. European Central Bank, Advisory Croup on Market Infrastructures for Securities and Collateral, Potential use cases for innovative technologies in securities post-trading, https:// www.ecb.europa.eu/paym/intro/publications/pdf/ecb.miptopical190111.en.pdf (10. 5. 2020.).

9. European Commission Consultation Document on an EU framework for markets in crypto-assets, https://ec.europa.eu/info/sites/info/files/business_economy_euro/banking_and_finance/documents/2019-crypto-assets-consultation-document_en.pdf (29. 4. 2020.).

10. European Securities and Markets Authority, The Distributed Ledger Technology Applied to Securities Markets, https://www.esma.europa.eu/sites/default/files/library/dlt_report_esma50-1121423017-285.pdf (10. 5. 2020.).

11. Final report of the Expert Group on Regulatory Obstacles to Financial Innovation: 30 recommendations on regulation, innovation and finance, https://ec.europa.eu/info/publications/191113-report-expert-group-regulatory-obstaclesfinancial-innovation_en (1. 6. 2020.).

12. Le Plan d'Action pour la Croissance et la Transformation des Entreprises (PACTE), https://www. economie.gouv.fr/files/files/2019/PACTE_Juin2019/bro-a4-pacte.pdf (8. 9. 2020.).

13. Malta Digital Innovation Authority Bill, https://parlament.mt/en/13th-leg/bills/biII-no-045-malta-digital-innovation-authority-bill/ (10. 9. 2020.).

14. Projet de loi portant modification de la loi modifiée du 1er août 2001 concernant la circulation de titres, http://legilux.public.lu/eli/etat/projet/pl/10486 (10. 9. 2020.).

15. Questions and Answers - Implementation of the Regulation (EU) No 909/2014 on improving securities settlement in the EU and on central securities depositories, https://www.esma.europa. eu/sites/default/files/library/esma70-708036281-2_csdr_qas.pdf (8. 9. 2020.).

16. Smjernice o izvješćivanju o internaliziranim namirama u skladu s člankom 9. CSDR-a, https:// www.esma.europa.eu/sites/default/files/library/esma70-151-367_csdr_guidelines_on_ internalised_settlement_reporting_hr.pdf (25. 8. 2020.). 
17. Smjernice o postupku izračuna pokazatelja za određivanje najvažnijih valuta u kojima se namira izvršava, https://www.esma.europa.eu/sites/default/files/library/esma70-708036281-66_ csdr_guidelines_on_relevant_currencies_hr.pdf (25. 8. 2020.).

18. Smjernice o postupku izračuna pokazatelja za određivanje velikog značaja CSD-a za državu članicu domaćina, https://www.esma.europa.eu/sites/default/files/library/esma70-70803628167_guidelines_on_substantial_importance_of_a_csd_hr.pdf (25. 8. 2020.).

19. Smjernice Pravila i postupci u slučaju neispunjavanja obveza sudionika CSD-ova, https://www. esma.europa.eu/sites/default/files/library/esma70-151-294_guidelines_on_csd_participant_default_rules_hr.pdf (25.8.2020.).

20. Smjernice Pristup središnjeg depozitorija vrijednosnih papira (CSD) transakcijskim unosima CCPova i mjesta trgovanja, https://www.esma.europa.eu/sites/default/files/library/esma7o151-298_guidelines_on_csd_access_to_trading_feeds_of_ccps_and_tvs_hr.pdf (25. 8. 2020.).

21. Smjernice Suradnja tijela u skladu s člancima 17. i 23. Uredbe (EU) br. 909/2014, https://www. esma.europa.eu/sites/default/files/library/esma70-151-435_csdr_guidelines_on_cooperation_between_authorities_hr.pdf(25.8.2020.).

22. The registration of securities holders, ECSDA, 2016, https://ecsda.eu/wp-content/uploads/2016_07_19_ECSDA_Registration_Report.pdf (10. 9. 2020.).

23. UNIDROIT Convention on Substantive Rules for Intermediated Securities, 9. 10. 2009., https:// www.unidroit.org/instruments/capital-markets/geneva-convention (5. 5. 2020.).

24. UNIDROIT Legislative guide on intermediated securities, https://www.unidroit.org/instr-capitalmarkets-legislative-guide (10. 6. 2020.).

\section{Summary}

\section{THE IMPACT OF MODERN TECHNOLOGIES ON INTERMEDIATED SECURITIES - NATIONAL MODELS AND GLOBAL PERSPECTIVES}

The development of modern, globally applicable technologies has had a special impact on public limited companies. One of those is the blockchain technology $(B C)$, a subcategory of the so-called Distributed Ledger Technology (DLT). Since shares constitute intangible securities, data on intangible securities and their holders are most often managed by a central body, i.e. the operator of the central depository of securities both in Croatian law and in the other legal systems. Moreover, it is commonly accepted that shares are held via intermediaries who are often globally linked, especially in cross-border trade. However, the question of whether the legal owner of securities is the investor or (some of) the intermediaries has been resolved in different ways on a comparative basis and has been subject to legal harmonisation. After presenting comparative models related to the question of the legal owner of intermediated securities, the author presents the characteristics of the Croatian legal system in the development context and present-day perspective, also bearing in mind the impact of European law. 
Having presented the fundamental features of $B C$ technology, in the final part of the paper the author analyses how this technology could be applied to the existing system of securities depository on the one hand, and how it impacts on intermediated securities.

Key words: Blockchain, Distributed Ledger Technology (DLT), intermediated securities, central securities depository (CSD). 